\title{
$\beta 1,3-N$-Acetylglucosaminyltransferase 1 Glycosylation Is Required for Axon Pathfinding by Olfactory Sensory Neurons
}

\author{
Timothy R. Henion, ${ }^{1,2}$ Denitza Raitcheva, ${ }^{1}$ Robert Grosholz, ${ }^{1}$ Franziska Biellmann, ${ }^{3}$ William C. Skarnes, ${ }^{4}$ \\ Thierry Hennet, ${ }^{3}$ and Gerald A. Schwarting ${ }^{1,2}$ \\ ${ }^{1}$ Shriver Center, Waltham, Massachusetts 02452, ${ }^{2}$ Department of Cell Biology, University of Massachusetts Medical Center, Worcester, Massachusetts \\ 01655, ${ }^{3}$ Institute of Physiology, University of Zurich, CH-8057 Zurich, Switzerland, and ${ }^{4}$ Wellcome Trust Sanger Institute, Wellcome Trust Genome \\ Campus, Cambridge CB10 1SA, United Kingdom
}

During embryonic development, axons from sensory neurons in the olfactory epithelium (OE) extend into the olfactory bulb (OB) where they synapse with projection neurons and form glomerular structures. To determine whether glycans play a role in these processes, we analyzed mice deficient for the glycosyltransferase $\beta 1,3-N$-acetylglucosaminyltransferase 1 ( $\beta 3 \mathrm{GnT} 1)$, a key enzyme in lactosamine glycan synthesis. Terminal lactosamine expression, as shown by immunoreactivity with the monoclonal antibody $1 \mathrm{~B} 2$, is dramatically reduced in the neonatal null OE. Postnatal $\beta 3 \mathrm{GnT}^{-1-}$ mice exhibit severely disorganized OB innervation and defective glomerular formation. Beginning in embryonic development, specific subsets of odorant receptor-expressing neurons are progressively lost from the $\mathrm{OE}$ of null mice, which exhibit a postnatal smell perception deficit. Axon guidance errors and increased neuronal cell death result in an absence of $\mathrm{P} 2$, I7, and M72 glomeruli, indicating a reduction in the repertoire of odorant receptor-specific glomeruli. By $\sim 2$ weeks of age, lactosamine is unexpectedly reexpressed in sensory neurons of null mice through a secondary pathway, which is accompanied by the regrowth of axons into the $\mathrm{OB}$ glomerular layer and the return of smell perception. Thus, both neonatal OE degeneration and the postnatal regeneration are lactosamine dependent. Lactosamine expression in $\beta 3 \mathrm{GnT}^{-1-}$ mice is also reduced in pheromone-receptive vomeronasal neurons and dorsal root ganglion cells, suggesting that $\beta 3 \mathrm{GnT} 1$ may perform a conserved function in multiple sensory systems. These results reveal an essential role for lactosamine in sensory axon pathfinding and in the formation of $\mathrm{OB}$ synaptic connections.

Key words: olfactory development; sensory neurons; odorant receptors; axon guidance; glycosyltransferase; lactosamine

\section{Introduction}

Odor stimuli are transmitted by olfactory sensory neurons that are widely dispersed in the nasal cavity to focal sites of synaptic contact in the olfactory bulb (OB), termed glomeruli. Populations of neurons expressing a given odorant receptor project axons that converge on one or a few glomeruli in each $\mathrm{OB}$ where they synapse with the dendritic arbors of mitral and tufted cells, forming the first central relay in olfactory perception (Ressler et al., 1993; Vassar et al., 1994; Mombaerts et al., 1996). The convergence of axons expressing the same odorant receptor to specific glomerular loci in the $\mathrm{OB}$ creates a representative map of receptor activation that is thought to be essential for encoding

Received Nov. 12, 2004; revised Jan. 3, 2005; accepted Jan. 5, 2005.

This work was supported by National Institutes of Health Grants DC00953 (G.A.S.) and DC06496 (T.R.H.) and by Swiss National Science Foundation Grant 631-062662.00 (T.H.). We thank J. S. Kauer and S. Tobet for critical reading of this manuscript and F. B. Jungalwala for project support. We gratefully acknowledge Drs. P. Mombaerts, F. Margolis, T. Schoenfeld, and J. Schwob for reagents provided. We also thank Dr. Kevin Mitchell and other members of the Baygenomics Consortium for generating the genetrapped $\beta 3 \mathrm{GnT} 1$ mice used in this study and the Consortium for Functional Genomics for providing Core-2 glycosyltransferase null mice.

Correspondence should be addressed to Gerald A. Schwarting or Timothy R. Henion, Shriver Center, 200 Trapelo Road, Waltham, MA 02452. E-mail: Gerald.Schwarting@umassmed.edu or Timothy.Henion@umassmed.edu. DOI:10.1523/JNEUROSCI.4654-04.2005

Copyright $\odot 2005$ Society for Neuroscience $\quad$ 0270-6474/05/251894-10\$15.00/0 odorant information for processing by higher centers in the brain.

A role for odorant receptors in glomerular targeting has emerged from genetic ablation and receptor swap studies in mice (Mombaerts et al., 1996; Wang et al., 1998), although a mechanism through which these receptors might affect the behavior of growth cones remains elusive and does not seem to be evolutionarily conserved (Dobritsa et al., 2003). However, known guidance factors are differentially expressed by olfactory neurons where they influence the patterning of olfactory projections. Semaphorin 3A (Sema3A), for example, is expressed by ensheathing glial cells and restricts the innervation of neuropilin- $1^{+}$axons to medial and lateral glomerular domains (Pasterkamp et al., 1998; Schwarting et al., 2000, 2004). In addition, genetic manipulation of ephrin expression levels alters the positioning of glomeruli (Cutforth et al., 2003). Thus, it is likely that olfactory axons are at least partially guided by cues on cells and axons in adjacent pathways. In addition, other molecules, such as $N$-cadherin, regulate axodendritic interactions required for protoglomerular formation but do not appear to directly influence pathfinding to glomeruli (Hummel and Zipursky, 2004).

Cell-surface carbohydrates are an additional source of neuronal heterogeneity (Crandall et al., 2000; Lipscomb et al., 2002; 
Gibson et al., 2004; Storan and Key, 2004). The stereotyped distribution of glycan-expressing glomeruli has led to the hypothesis that glycans may directly influence targeting of sensory axons (Lipscomb et al., 2003). One such glycan is terminal lactosamine, which is expressed by neurons that preferentially innervate ventromedial targets in embryonic rodents, consistent with a role in patterning olfactory connectivity (Schwarting and Crandall, 1991). Interestingly, Dodd and Jessell (1985) showed that lactosamine was also expressed by subsets of dorsal root ganglion (DRG) neurons, where it was suggested to influence the organization of projections to specific dorsal horn laminas. $\beta 1,3-N$ acetylglucosaminyltransferase $1(\beta 3 \mathrm{GnT} 1)$ is a member of a family of $\beta 3 \mathrm{GnT}$ s that regulate the initiation and extension of lactosamine chains on glycoproteins and glycolipids. We show here that $\beta 3 \mathrm{GnT} 1$ determines lactosamine expression by sensory neurons in both the olfactory epithelium (OE) and the vomeronasal organ, in addition to nociceptive neurons in DRGs. Furthermore, we demonstrate that $\beta 3 \mathrm{GnT} 1$ is required for the formation of sensory axon connections and normal glomerular formation during olfactory development.

\section{Materials and Methods}

Animals. $33 \mathrm{GnT} 1$ null mice were established from the KST308 embryonic stem cell line, which harbors a secretory trap vector insertion in the $\beta 3 \mathrm{GnT} 1$ locus (available from the Baygenomics Consortium) (Mitchell et al., 2001). The pGT1TMpfs plasmid used for producing KST308 cells encodes a splice acceptor site that directs the expression of a fusion transcript consisting of the $\beta 3 \mathrm{GnT} 1$ exon 1 sequence upstream of the integration site spliced to a vector-derived rat CD4 transmembrane domain sequence fused in frame with the $\beta$-geo reporter gene. $5^{\prime}$-Rapid amplification of cDNA ends analysis determined that the vector integrated in the second $\beta 3 \mathrm{GnT} 1$ exon at position 686 of the coding region (GenBank accession number NM_016888), predicting the expression of a severely truncated $\beta 3 \mathrm{GnT} 1$ fusion product from the disrupted locus. $\beta 3 \mathrm{GnT} 1$ mice were generated on a mixed 1290 Oa $\times$ C57BL/6 background and backcrossed to C57BL/6 for four generations before our analysis of heterozygous intercrosses. I7-Internal ribosomal entry site (IRES)-taugreen fluorescent protein (GFP), M72-IRES-tau-GFP, and P2-IRES-taulacZ mice were generated by Dr. Peter Mombaerts (Rockefeller University, New York, NY). P2-IRES-tau-lacZ mice have been previously backcrossed over several generations to the background of the $\beta 3 \mathrm{GnT} 1$ line. Mice were housed according to standard National Institutes of Health and institutional care guidelines.

In situ hybridization. Antisense and sense riboprobes corresponding to the $1100 \mathrm{bp}$ of $\beta 3 \mathrm{GnT} 1$ coding sequence immediately downstream of the transmembrane domain were subcloned into pBluescript-II $\mathrm{SK}^{+}$. Digoxigenin-labeled riboprobes (Roche Applied Science, Indianapolis, IN) were synthesized and hybridized to $4 \%$ paraformaldehyde-fixed, cryosectioned tissue as described previously (Henion et al., 2001). Odorant receptor riboprobes, prepared according to Iwema et al. (2004), were provided by Dr. James Schwob (Tufts University, Boston, MA).

Histology and immunocytochemistry. Histochemical and immunocytochemical analysis was conducted on free-floating sections prepared by $4 \%$ paraformaldehyde fixation and sectioning on a sliding microtome at $50 \mu \mathrm{m}$ thickness. Placental alkaline phosphatase labeling of axons in genetrap mouse lines was performed using nitroblue-tetrazoliumchloride/5-bromo-4-chloro-3-indolyl-phosphate substrate, as described previously (Leighton et al., 2001). The mouse monoclonal antibody 1B2 (IgM) (Young et al., 1981) against the lactosamine epitope was obtained from American Type Culture Collection (Manassas, VA). Monoclonal antibody to olfactory marker protein (OMP) was a generous gift from Dr. Frank Margolis (University of Maryland, Baltimore, MD). Unless otherwise noted, 1B2 and OMP immunoreactivity was localized with biotinylated secondary antibodies in combination with avidin-biotinhorseradish peroxidase (Vectastain standard ABC kit; Vector Laboratories, Burlingame, $\mathrm{CA}$ ), visualized with a diaminobenzidine-nickel reaction, as described previously (Schwarting et al., 2000). P2 glomeruli in $\beta 3$ GnT1/P2-IRES-tau-LacZ mice were visualized with 1:2000 rabbit anti- $\beta$-galactosidase (Cortex Biochem) and cyanine 3-conjugated secondary antibody against rabbit IgG (Jackson ImmunoResearch, West Grove, PA).

Cell death and proliferation analysis. Assays for apoptosis in the $\mathrm{OE}$ were performed using protocols specified in the DeadEnd terminal deoxynucleotidyl transferase-mediated biotinylated UTP nick end labeling (TUNEL) system (Promega, Madison, WI) with the modification of using Vectastain $\mathrm{ABC}$ kit amplification with diaminobenzidine-nickel substrate detection. Relative levels of cell death between $\beta 3 \mathrm{GnT} 1^{+/-}$and $\beta 3 \mathrm{GnT} 1^{-1-}$ mice were determined by counting the number of $\mathrm{TUNEL}^{+}$cells per square millimeter of coronal dorsal OE sections using three animals per group. To assay $\mathrm{OE}$ basal cell proliferation, mice were administered a single $12.5 \mathrm{mg} / \mathrm{kg}$ dose of 5-bromo-2'-deoxyuridine (BrdU) 30 min before killing. Tissues were fixed in $4 \%$ paraformaldehyde and reacted with biotinylated rat anti-BrdU antibody (Axyll) and biotinylated anti-rat secondary antibody before visualization with Vectastain $\mathrm{ABC}$ and diaminobenzidine-nickel substrate.

Buried food olfactory test. Mice were tested for their ability to find buried food according to Wrenn et al. (2003) with minor modifications. Briefly, mice were weaned at day 14 and tested beginning on day 16 . Testing was conducted for 3 consecutive days each week over the course of 4 weeks. The test was also conducted on 16-week-old adult mice. Three mutant, three heterozygote, and three wild-type littermates were habituated to the food reward by placing pieces of cookies in the cage overnight and then depriving the mice of food for $6 \mathrm{~h}$. The test was conducted in $44 \times 25 \mathrm{~cm}$ rat cages, and a piece of cookie was hidden under $2.5 \mathrm{~cm}$ of clean standard bedding. One mouse was placed in the cage and timed for the latency to find and begin eating the cookie. A maximum of $10 \mathrm{~min}$ was allowed.

\section{Results \\ B3GnT1 mRNA expression during nervous system development}

Lactosamine ( $\mathrm{Gal} \beta 1,4-\mathrm{GlcNAc}$ ) is a common core component of complex $N$-linked glycans and some $O$-glycans and glycolipids (Fig. 1a). Olfactory sensory neurons are unique in the expression of a form of terminal lactosamine that is recognized by the monoclonal antibody $1 \mathrm{~B} 2$. $\beta 3 \mathrm{GnT}$ enzyme activities play a key role in regulating lactosamine initiation and extension in different tissues. To investigate how lactosamine synthesis is determined during olfactory development, we used in situ hybridization to map the expression of several $\beta 3 \mathrm{GnT}$ Ts with established roles in lactosamine extension. Of five potential candidates examined, $\beta 3 \mathrm{GnT} 1, \beta 3 \mathrm{GnT} 3, \beta 3 \mathrm{GnT} 5, \beta 3 \mathrm{GnT} 6$, and iGnT (Sasaki et al., 1997; Zhou et al., 1999; Henion et al., 2001; Yeh et al., 2001; Iwai et al., 2002), only $\beta 3 \mathrm{GnT} 1$ was broadly transcribed throughout all OE regions, similar to the established pattern of $1 \mathrm{~B} 2$ reactivity (Crandall et al., 2000). At embryonic day 13 (E13), $\beta 3 \mathrm{GnT1}$ was mostly restricted to olfactory sensory neurons, endothelial cells, and the thymus, with no detectable expression by any neuronal population in the brain (Fig. $1 b$ ). $\beta 3 \mathrm{GnT} 1$ was also transcribed in other developing regions of the peripheral nervous system, including dorsal root, trigeminal, and IXth cranial ganglia (data not shown). Expression of $\beta 3 \mathrm{GnT} 1$ was strikingly high in vomeronasal neurons of the accessory olfactory system, although most neurons in the OE transcribed $\beta 3 \mathrm{GnT} 1$ at relatively uniform levels (Fig. $1 c, d$ ). $\beta 3 \mathrm{GnT} 1$ expression continued throughout postnatal development in sensory neurons adjacent to the mature population of $1 \mathrm{~B} 2{ }^{+}$neurons located near the apical OE surface (Fig. 1d,e).

\section{Lactosamine-deficient $\beta 3 \mathrm{GnT}^{-/-}$mice exhibit neuronal loss}

Direct regulation of lactosamine expression by $\beta 3 \mathrm{GnT} 1$ was established using null mice generated from embryonic stem cells identified in a secretory trap insertional mutagenesis screen (Mitchell et al., 2001). Integration of the secretory trap vector 

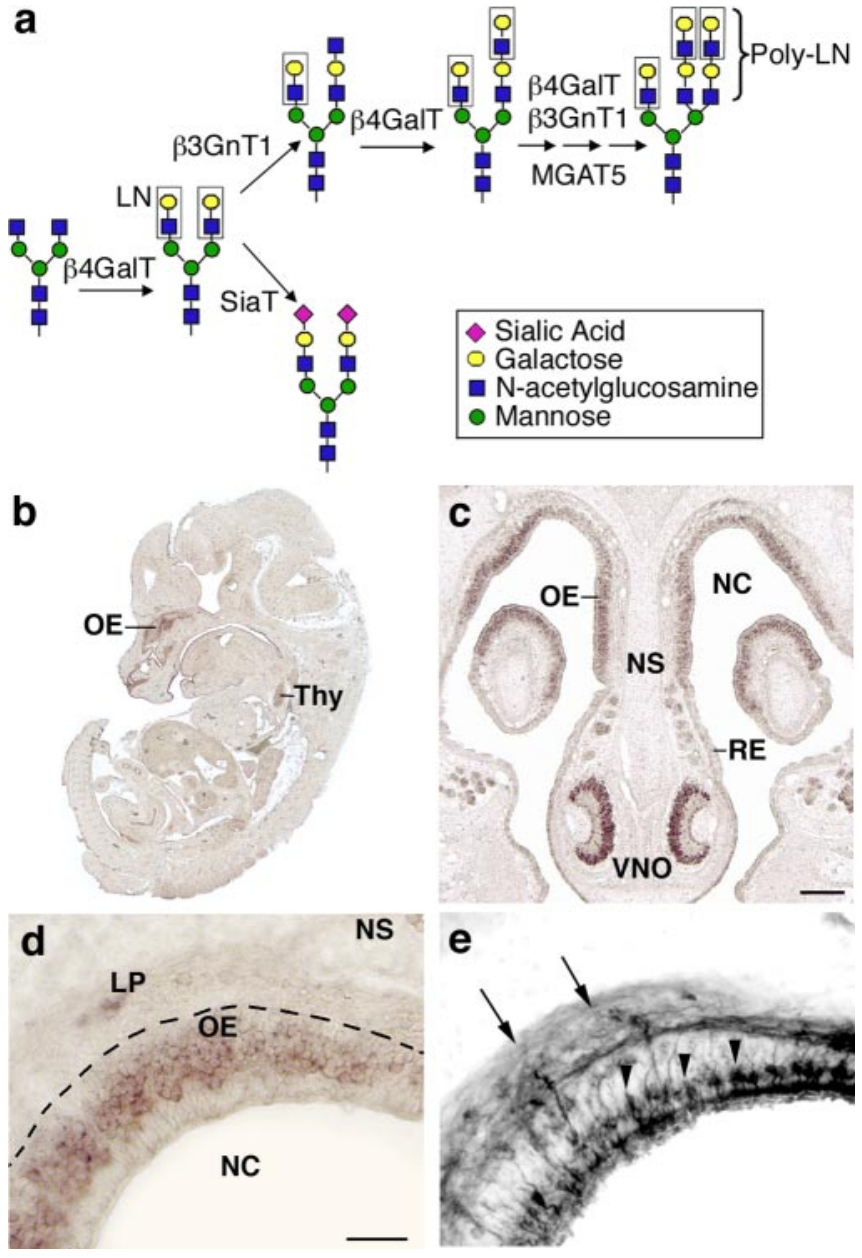

Figure 1. $\quad \beta 3 \mathrm{GnT1}$ and lactosamine are strongly expressed in the developing olfactory system. $\boldsymbol{a}$, The lactosamine disaccharide recognized by $1 \mathrm{~B} 2$ antibodies (boxes) occurs widely on $\mathrm{N}$-glycans but is typically capped by sialic acid or other glycans. Lactosamine can be extended by tissue-specific $\beta 3 \mathrm{GnT}$ and $\beta 4 \mathrm{GalT}$ activities to form polylactosamines, which frequently occur on MGAT 5 branched glycans. The $\beta 3 \mathrm{GnT} 1$ dependence of $1 \mathrm{~B} 2$ reactivity may indicate preferential recognition of polylactosamine in tissues. $\boldsymbol{b}-\boldsymbol{d}$, In situ hybridization analysis of $\beta 3 \mathrm{GnT1}$ expression in the mouse in a sagittal section through an E13 embryo (b), E15 coronal nose (c), and P1 OE $(\boldsymbol{d})$. The dashed line in $\boldsymbol{b}$ denotes the border between the $0 \mathrm{E}$ and the underlying lamina propria (LP).e, ICC showing 1B2 ${ }^{+}$sensory neurons (arrowheads) and axons (arrows) in the section adjacent to $\boldsymbol{d}$. NC, Nasal cavity; NS, nasal septum; RE, respiratory epithelium; Thy, thymus; VNO, vomeronasal organ. Scale bars: $c, 200 \mu \mathrm{m} ; \boldsymbol{d}, \boldsymbol{e}, 50 \mu \mathrm{m}$.

encoding $\beta$-geo and human placental alkaline phosphatase (PLAP) truncates $\beta 3 \mathrm{GnT} 1$ after 228 aa, removing the "DxD" and other conserved C-terminal motifs required for $\beta 1,3-$ glycosyltransferase activity (Malissard et al., 2002). Mutant mice had no obvious phenotypic abnormalities and survived postnatally similar to control littermates. Immunocytochemical (ICC) analysis of postnatal day 1 (P1) $\beta 3 \mathrm{GnT}^{-1-}$ OEs revealed that $1 \mathrm{~B} 2$ reactivity on cell bodies was widely abolished, with only residual lactosamine expression by scattered neurons (Fig. 2a). Mature $\mathrm{OMP}^{+}$neurons, which normally occupy several layers of apical cells near the $\mathrm{OE}$ surface, were reduced to a single cell layer in $\beta 3 \mathrm{GnT}^{-1-}$ mice (Fig. $2 a$ ). This loss of mature neurons correlated with a $>20 \%$ decrease in relative $\mathrm{OE}$ thickness between $\beta 3 \mathrm{GnT}^{-1-}$ and $\beta 3 \mathrm{GnT1}^{+/-}$mice from P1 $(0.77 \pm 0.05 ; 52.8$ $\mu \mathrm{m} \beta 3 \mathrm{GnT}^{-/-}$vs $68.3 \mu \mathrm{m} \beta 3 \mathrm{GnT1}^{+/-}$) through P25 (0.78 \pm $0.01 ; 46.3 \mu \mathrm{m} \beta 3 \mathrm{GnT}^{-1-}$ vs $59.0 \mu \mathrm{m} \beta 3 \mathrm{GnT}^{+/-}$).

The PLAP enzyme in $\beta 3 \mathrm{GnT} 1$ mice is expressed from the disrupted genomic locus as a bicistronic RNA with $\beta$-geo under translational control of an IRES. PLAP histochemical activity selectively labels axon processes of neurons transcribing secretorytrapped genes (Leighton et al., 2001) and was used to map the projections of olfactory neurons expressing $\beta 3 \mathrm{GnT} 1$. At P1, protoglomeruli were visible in $\beta 3 \mathrm{GnT} 1^{+/-}$mice but absent from mutant OBs (data not shown). By P10, glomeruli were morphologically prominent in control animals, but the glomerular layer of $\beta 3 \mathrm{GnT} 1^{-1-}$ mice was widely devoid of innervation by both PLAP-labeled and $1 \mathrm{~B}^{+}{ }^{+}$axons (Fig. $2 b$ ). ICC analysis with OMP revealed that the $\mathrm{OB}$ nerve layer was reduced in thickness compared with control mice, indicating a decrease in the number of axons innervating the $\mathrm{OB}$ (Fig. $2 b$ ). The $\mathrm{OMP}^{+}$axons that remained in the mutant nerve layer mostly failed to enter the glomerular neuropil or segregate into discreet glomeruli, suggesting that $\beta 3 \mathrm{GnT} 1$ loss caused defects in axon extension through the nerve layer into the developing glomerular layer. Residual glomeruli that did form in $\beta 3 \mathrm{GnT}^{-1-}$ mice were excluded from the dorsal $\mathrm{OB}$, a region that appears particularly sensitive to innervation defects (Wang et al., 2004; Yu et al., 2004). The failure of glomerulogenesis correlated with an overall $22 \%$ reduction in $\mathrm{OB}$ size in null adults (data not shown).

\section{Increased cell death and precursor proliferation in $\beta 3 \mathrm{GnT}^{-1-}$ mice}

We examined whether the decreases observed in $\mathrm{OB}$ innervation and number of $1 \mathrm{~B} 2 / \mathrm{OMP}^{+}$neurons in the $\mathrm{OE}$ of early postnatal mutant mice could be related to changes in neuronal cell death. Developmental apoptosis in the mouse OE normally peaks at approximately E16 and declines toward birth (Voyron et al., 1999). In P1 null mice, a significant elevation in the number of cells undergoing apoptosis was detected by TUNEL analysis $\left(161 \pm 45 / \mathrm{mm}^{2} \beta 3 \mathrm{GnT1}^{-/-}\right.$vs $60+/-2 / \mathrm{mm}^{2} \beta 3 \mathrm{GnT1}^{+/-}$; $p>0.01$ ) (Fig. 3a). This paralleled the failure in glomerular formation and suggested that olfactory neuron cell death may result from failed connectivity with the $\mathrm{OB}$. By $\mathrm{P} 10$, the number of apoptotic cells in all mice had decreased significantly and was not substantially increased in null mice relative to controls. BrdUlabeling analysis, however, revealed a striking increase in the rate of basal progenitor cell proliferation in P10 null OEs (Fig. 3b). Cell division was not obviously altered at P1, P25, or adult ages. The transient increase in neurogenesis observed $>1$ week after the peak of cell death is consistent with delayed neurogenic responses elicited after bulbectomy or methyl bromide-induced OE lesions (Schwartz-Levy et al., 1991; Schwob et al., 1995).

\section{Specific odorant receptor subsets are lost from the} B3GnT1 ${ }^{-1-}$ OE

Survival of specific olfactory neuronal populations was examined by analyzing odorant receptor gene expression. During late embryogenesis and the first two postnatal weeks, the number of neurons expressing the $\mathrm{P} 2$ odorant receptor normally undergoes a rapid expansion, paralleling the increased size and complexity of the nasal cavity (Royal and Key, 1999). We used in situ hybridization to examine odorant gene expression throughout development. P2 neurons were progressively lost from the $\mathrm{OE}$ in $\beta 3 \mathrm{GnT}^{-/-}$mice, beginning in embryonic development (Fig. 4). At E17, the number of P2 neurons in the $\beta 3 \mathrm{GnT}^{-1-} \mathrm{OE}$ was $72 \%$ that of control littermates. The relative number of neurons declined to $58 \%$ by P1 and further decreased to $45 \%$ at P10, whereas in adult mutants, $<15 \%$ of $\mathrm{P} 2$ neurons survived.

To further investigate the fate of odorant receptor-specific neurons, we crossed $\beta 3 \mathrm{GnT} 1$ mice to I7-IRES-tau-GFP odorant receptor reporter strain and compared $\mathrm{GFP}^{+}$neurons in mutant 

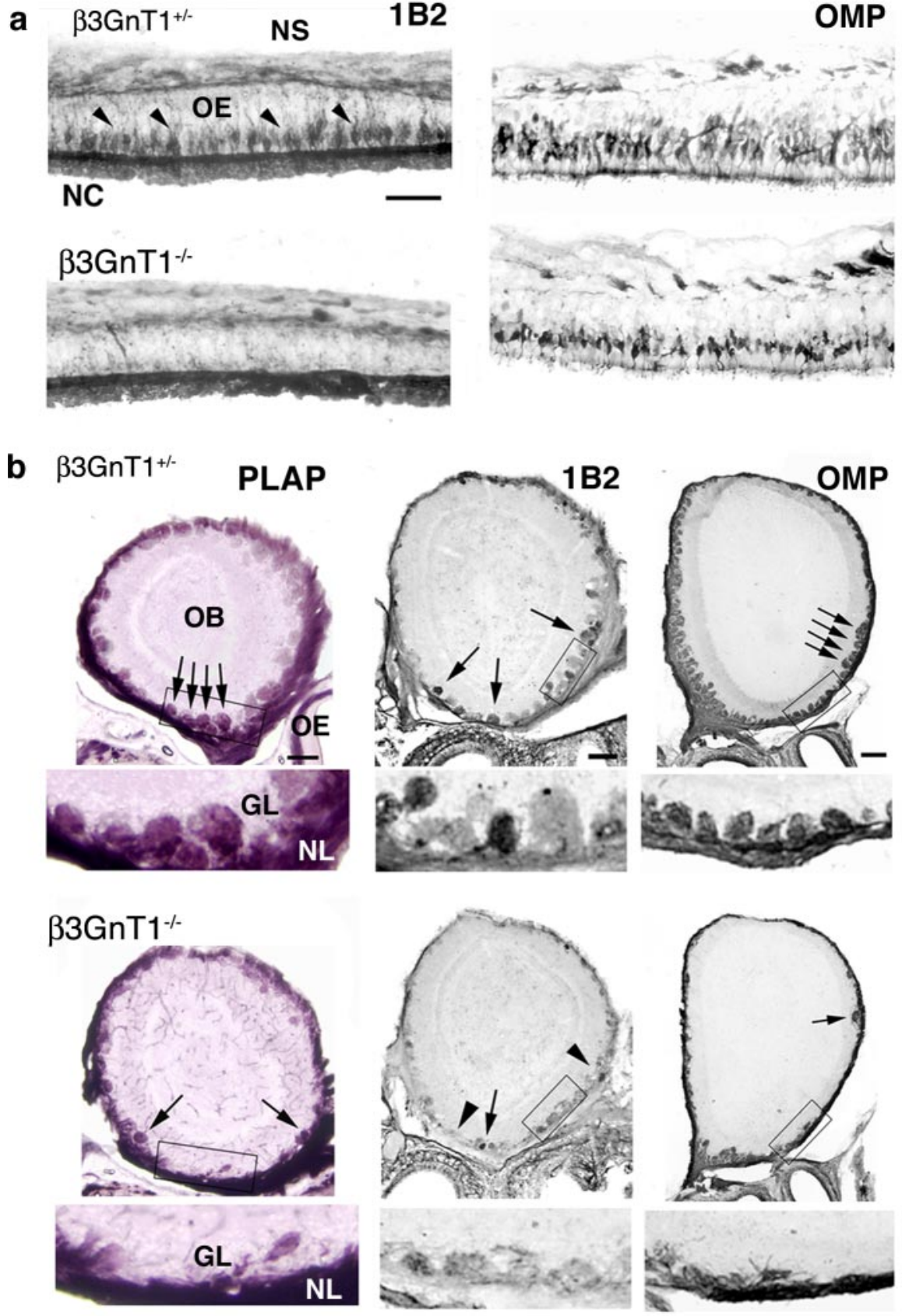

Figure 2. Mature olfactory sensory neurons and OB glomeruli are lost in lactosamine $\beta 3 \mathrm{GnT1}$ null mice. $\boldsymbol{a}, 1 \mathrm{~B} 2$ and OMP ICC analysis of P1 $0 \mathrm{E}$. 1B2 expression in sensory neurons (arrowheads) is virtually absent in $\beta 3 \mathrm{GnT} 1$ null mice. Residual $1 \mathrm{~B} 2$ labeling of the luminal surface of the $\mathrm{OE}$ is mucin dependent and is not present in Core-2 $\mathrm{O}$-glycan-deficient mice (data not shown). The number of $\mathrm{OMP}^{+}$neurons is greatly reduced in null mice, indicating that lactosamine is required for maintenance of the majority of fully differentiated sensory neurons. NC, Nasal cavity; NS, nasal septum. Scale bar, $50 \mu \mathrm{m}$. $\boldsymbol{b}$, Histochemical staining for PLAP activity and ICC analysis of $1 \mathrm{~B} 2$ and $\mathrm{OMP}$ expression in coronal sections from P10 OBs. In null mice, the number of glomeruli (arrows) is reduced, and most $1 B 2$ reactivity is lost (arrowheads). Higher-magnification views of boxed areas, shown below each figure, demonstrate the severe loss of normal glomerular structures at this age. GL, Glomerular layer; NL, nerve layer. Scale bar, $200 \mu \mathrm{m}$.

mice and control littermates. $\beta 3 \mathrm{GnT} 1$ null mice displayed a loss of I7-GFP neurons over time similar to that observed for P2 neurons. A noticeable deletion of I7 neurons began by E17 and progressed with postnatal development until $<20 \%$ of I7 neurons remained in the adult null OE (data not shown).

\section{Odorant receptor-specific axon trajectories}

$\mathrm{P} 2$ axon projections were visualized by crossing $\beta 3 \mathrm{GnT} 1$ mice to the P2-IRES-tau-LacZ reporter strain (Mombaerts et al., 1996) and staining for $\beta$-galactosidase protein expression. I7 and M72 axon trajectories were visualized by crossing $\beta 3 \mathrm{GnT} 1$ and I7- and M72-IRES-tau-GFP mice, respectively. ICC analysis of OEs from P2 mice at different developmental ages confirmed the loss of $\beta$-galactosidase ${ }^{+} \mathrm{P} 2$ neurons observed by in situ hybridization. Serial sections from $\mathrm{E} 17 \beta 3 \mathrm{GnT} 1^{+/-}$OBs revealed labeled fibers that converged on the ventral nerve layer and formed a typical P2 protoglomerulus (Fig. $5 a$ ). In contrast, axons from $\beta 3 \mathrm{GnT} 1^{-1-}$ mice failed to penetrate the developing glomerular layer, but instead remained in the nerve layer adjacent to their normal protoglomerular position. At later time points, when P2 axons had condensed to form a mature glomerulus in $\beta 3 \mathrm{GnT} 1^{+/-}$mice, $\mathrm{P} 2$ axons were not detected in the mutant nerve layer, indicating that axons reaching the $\mathrm{OB}$ at $\mathrm{P} 1$ were not maintained (Fig. 5a).

A glomerular formation defect analogous to that for $\mathrm{P} 2$ also occurred for I7 axons of mutant mice. By P7, very few $\mathrm{GFP}^{+}$I7 fibers reached appropriate positions in the ventral nerve layer, and only rarely did I7 axons grow into the glomerular layer (Fig. 5b). Axons from the residual neurons expressing I7 in adult mutant OEs were not found in the nerve layer, although this could reflect a decrease in the number of remaining I7 axons below a critical threshold required to sustain glomerular formation (Ebrahimi and Chess, 2000).

We crossed $\beta 3 \mathrm{GnT1}$ mice with M72IRES-tau-GFP mice to quantify the number of M72-GFP neurons in null mice and to analyze axon trajectories of neurons originating in the dorsal $\mathrm{OE}$ and projecting to the dorsal, caudal OB. Compared with wild-type controls at $\mathrm{P} 1$, the $\mathrm{OE}$ of mutant mice displayed an $\sim 60 \%$ reduction in M72 neurons (Fig. 6a), which increased over early postnatal development similar to the depletion of P2 and I7 neuron populations. Despite the ongoing loss of M72-GFP neurons in the OE, bundles of $\mathrm{GFP}^{+}$axons were still detectable in the nerve layer of null mice, growing toward their targets in the dorsal, caudal OB. Unlike the P2 and I7 crosses to $\beta 3 \mathrm{GnT} 1$ null mice, in which few labeled axons were seen in the nerve layer at $\mathrm{P} 10$, axon guidance appeared to be perturbed in $\beta 3 \mathrm{GnT1} 1^{-1-} / \mathrm{M} 72$-IRES-tau-GFP mice. In control mice, the medial M72 glomerulus was typically positioned in the dorsomedial quadrant of the extreme caudal end of the OB (Fig. $6 b$ ). In $\beta 3 \mathrm{GnT1}$ mutant mice, M72 axons failed to form a glomerulus in the normal M72 position (Fig. 6b, right panel, arrows), and in some examples, axons continued to grow to the dorsal extent of the OB. Thus, although there were a decreased number of M72 
neurons in $\beta 3 \mathrm{GnT} 1^{-1-} \mathrm{OE}, \mathrm{M} 72$ axons grew into the dorsal nerve layer but appeared to bypass their intended target and failed to form normal glomeruli.

$\mathrm{OB}$ reinnervation in $\beta 3 \mathrm{GnT} 1^{-1-}$ mice is associated with

\section{lactosamine reexpression}

The above results demonstrate a unique requirement for $\beta 3 \mathrm{GnT} 1$ activity in sensory axon pathfinding and subsequent survival during olfactory development. In adult $\beta 3 \mathrm{GnT} 1^{-1-}$ OBs, however, an unexpected reinnervation of OMP and 1B2reactive axons occurred (Fig. $7 a$ ). After P15, OMP-labeled axons entered the ventral OB, forming morphologically abnormal glomeruli that were primarily excluded from the most dorsal OB regions. In parallel to the reinnervation, the ratio of OE thicknesses between null and control animals also returned to normal $(0.97 \pm$ $0.03 ; 39.2 \mu \mathrm{m} \beta 3 \mathrm{GnT}^{-1-}$ vs $40.5 \mu \mathrm{m}$ $\left.\beta 3 \mathrm{GnT}^{+/-}\right)$. Surprisingly, double-label immunofluorescence revealed that all reinnervating $\mathrm{OMP}^{+}$fibers in $\beta 3 \mathrm{GnT} 1^{-/-}$ OBs expressed lactosamine, unlike the mosaic distribution of 1B2-reactive glomeruli typical of control animals (Fig. $7 a, b)$. This expanded distribution suggests that lactosamine was required for either regrowth into the $\mathrm{OB}$ or survival of sensory neurons. The mechanism for this lactosamine reexpression remains unclear. Reverse transcription-PCR analysis of mRNA from mutant OEs did not identify alternatively spliced $\beta 3 \mathrm{GnT} 1$ transcripts lacking $\beta$-geo (data not shown), indicating that secondary changes in other glycosyltransferase activities are a likely mechanism for the lactosamine neosynthesis. The reexpression of lactosamine in $\beta 3 \mathrm{GnT}^{-/-}$mice is unique to olfactory neurons, because sensory neurons that lose lactosamine in other regions of the peripheral nervous system do not undergo such compensatory changes (see below).

Mice with targeted gene deletions in odorant receptor signaling components frequently die from an inability to recognize olfactory cues required for suckling (Brunet et al., 1996; Belluscio et al., 1998; Wong et al., 2000). In contrast, newborn $\beta 3 \mathrm{GnT}^{-/-}$pups nursed normally, indicating some level of olfactory function. The aberrant innervation of the glomerular layer in mutant mice, however, affected smell perception in food-finding tests of olfactory function. Between P14 and P28, fasted null mice took significantly longer than control littermates to locate hidden food rewards (Fig. 7c). Interestingly, mutant mice regained near-normal perfor-

TUNEL Analysis
a $\quad \beta 3 \mathrm{GnT1} 1^{+/-}$
$\beta 3 \mathrm{GnT} 1^{-/-}$
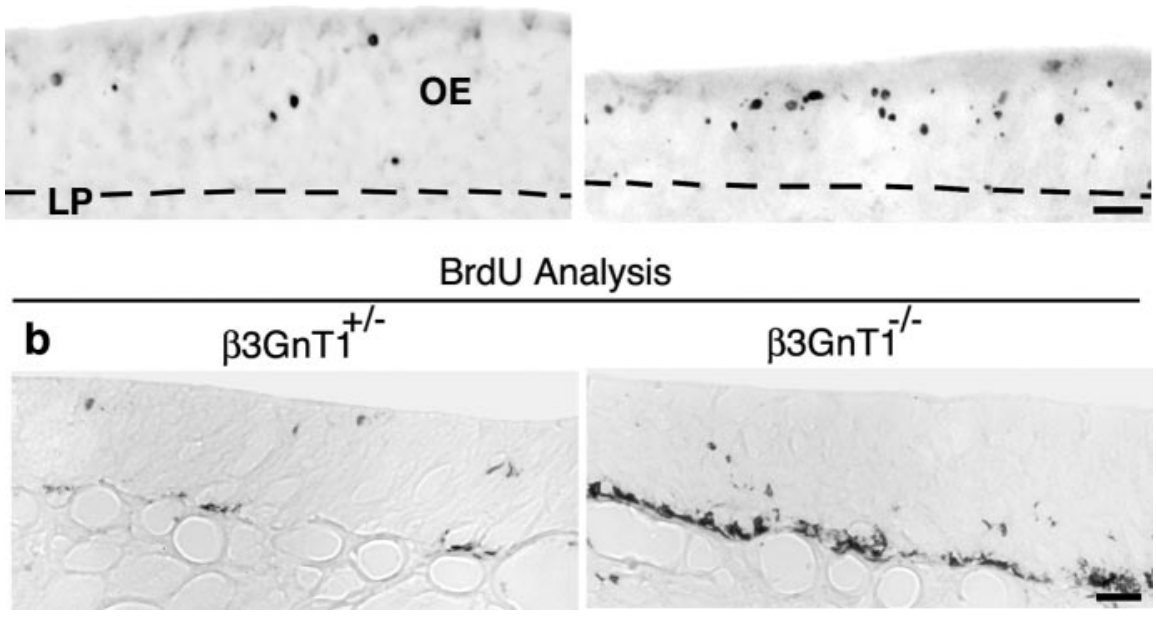

Figure 3. Apoptosis and compensatory neurogenesis in $\beta 3 \mathrm{GnT1}$ null mice. $\boldsymbol{a}$, TUNEL analysis of neonatal $\mathrm{OE}$ cell death, showing increased sensory neuron apoptosis in P1 null mice. Most TUNEL ${ }^{+}$cells are found at more apical levels of the $0 \mathrm{E}$, suggesting that loss of lactosamine does not induce cell death of neuronal progenitors located in the basal cell layer. The dashed line marks the boundary between $\mathrm{OE}$ and the underlying lamina propria (LP). $\boldsymbol{b}, \mathrm{BrdU}$ analysis of cell division in the P10 $0 \mathrm{E}$. The proliferation of neural progenitors in the basal $0 \mathrm{E}$ is dramatically increased in $\beta 3 \mathrm{GnT} 1^{-/-}$mice 1 week after the peak of apoptosis shown in $\boldsymbol{a}$. Scale bars: $\boldsymbol{a}, \boldsymbol{b}, 25 \mu \mathrm{m}$.

\section{$\beta 3 \mathrm{GnT1}^{+/-}$}
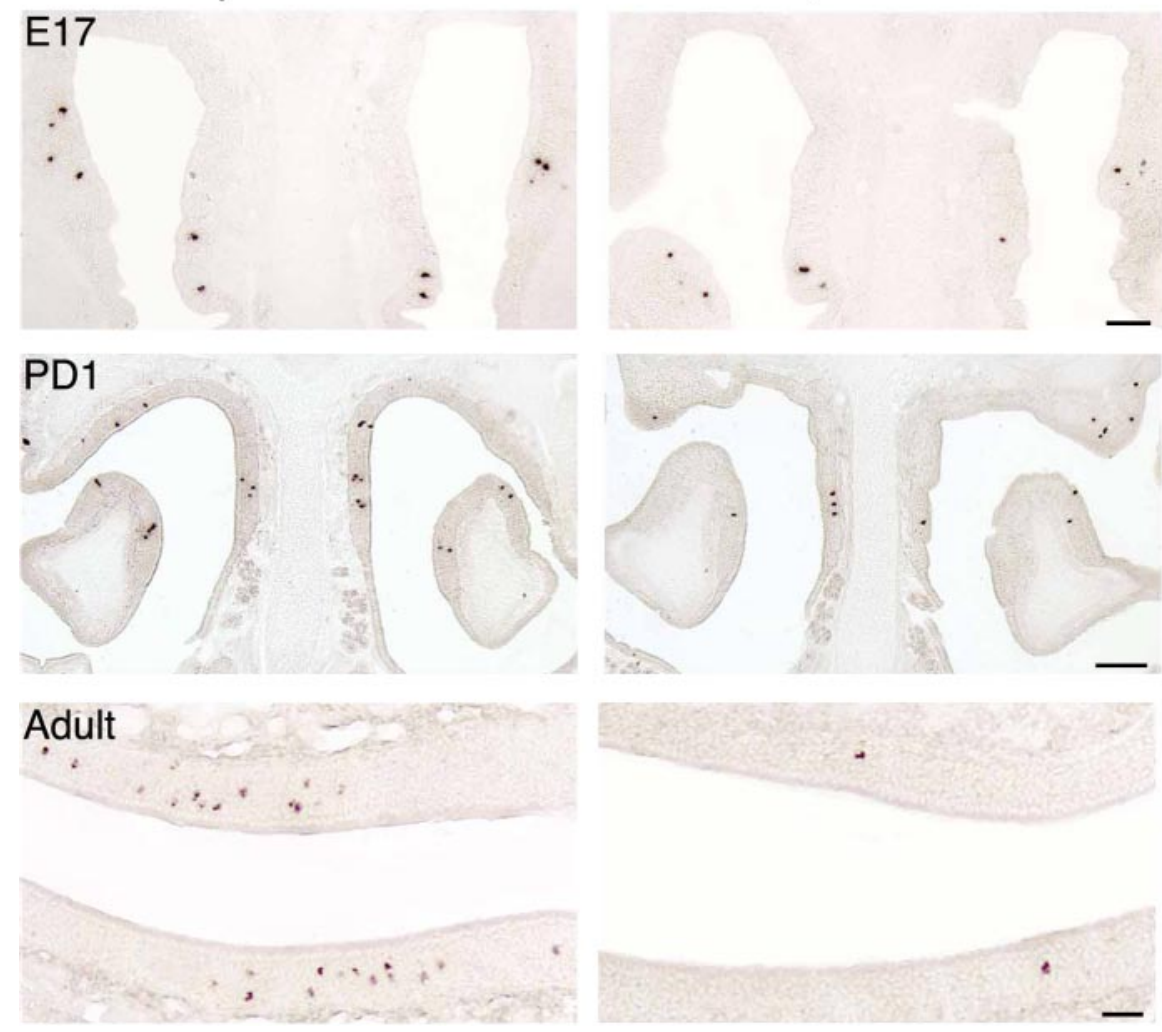

Figure 4. $\quad P 2$ odorant receptor-expressing sensory neurons are progressively lost in null mice. In situ hybridization for $\mathrm{P} 2$ odorant receptor mRNA expression in the $0 \mathrm{E}$ of $\beta 3 \mathrm{GnT1}$ mice at different ages. The $\mathrm{P} 2$ odorant receptor-expressing subset is restricted to zone III of the $0 \mathrm{E}$, located at an intermediate position along the dorsoventral axis of the nasal cavity (Wang et al. 1998). The number of neurons expressing the $P 2$ odorant receptor declines progressively, beginning in late embryonic development and continuing into adulthood. In adult null mice, $<15 \%$ of $P 2$ neurons remain. Scale bars: top, $100 \mu \mathrm{m}$; middle, $200 \mu \mathrm{m}$; bottom, $100 \mu \mathrm{m}$. 
a
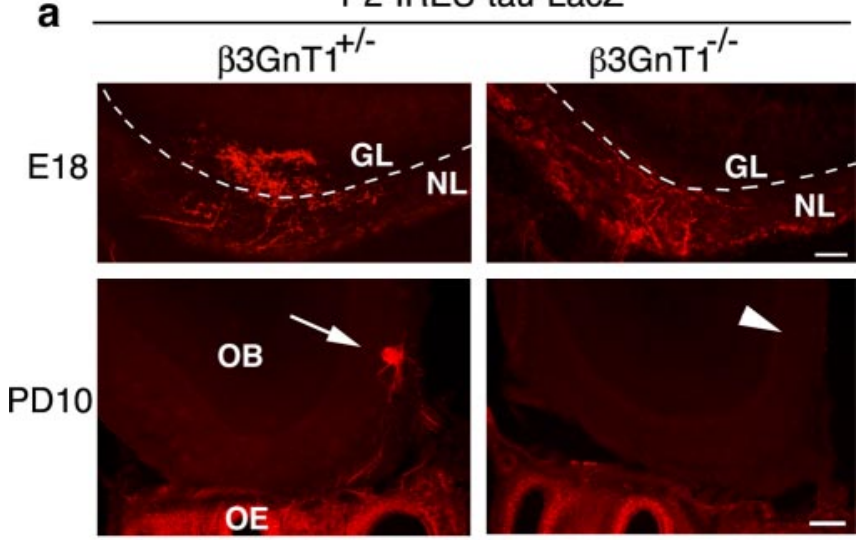

b

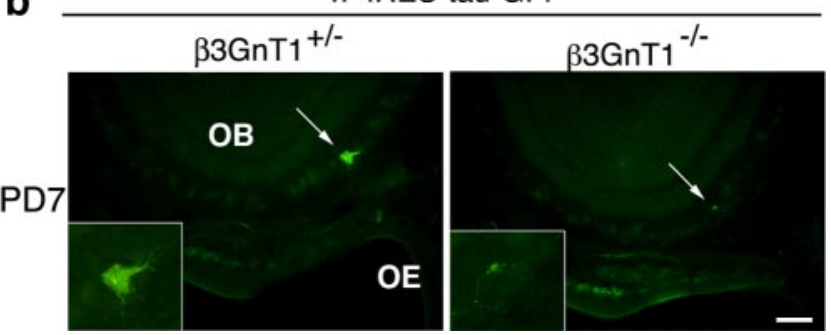

Figure 5. $\mathrm{P} 2$ and $\mathrm{I} 7 \mathrm{glomeruli}$ fail to form in $\beta 3 \mathrm{GnT}^{-1-}$ mice. $\boldsymbol{a}$, Targeting of the $\mathrm{OB}$ by $\mathrm{P} 2$ axons in E18 and P10 $\beta 3$ GnT1/P2-IRES-tau-LacZ mice, visualized by anti- $\beta$-galactosidase immunoreactivity. AtE18, $\beta 3 \mathrm{GnT} 1^{-1-} \mathrm{P} 2$ axons fail to grow through the nerve layer (NL) into the forming glomerular layer (GL) (top). P2 axons innervate the medial OB glomerulus (arrow) in $\mathrm{P} 10 \beta 3 \mathrm{GnT} 1^{+/-}$mice but are completely absent from the glomerular layer of $\beta 3 \mathrm{GnT} 1^{-1-}$ mice. The arrowhead denotes the approximate position of the missing $\mathrm{P} 2$ glomerulus in the mutant OB. $\boldsymbol{b}$, Medial I7-glomeruli in P7 $\beta 3$ GnT1//7-IRES-tau-GFP mice, visualized by GFP fluorescence. Arrows indicate the position of the I7 glomerulus in $\beta 3 \mathrm{GnT}^{+/-}$mice and several innervating 17 fibers in the same region of $\beta 3 \mathrm{GnT}^{-1-}$ mice. Inset shows higher-magnification of images in each panel of $\boldsymbol{b}$. Scale bars: $\boldsymbol{a}$, top, $25 \mu \mathrm{m}$; bottom, $200 \mu \mathrm{m} ; \boldsymbol{b}, 200 \mu \mathrm{m}$.

$\beta 3 \mathrm{GnT}^{+/-}$
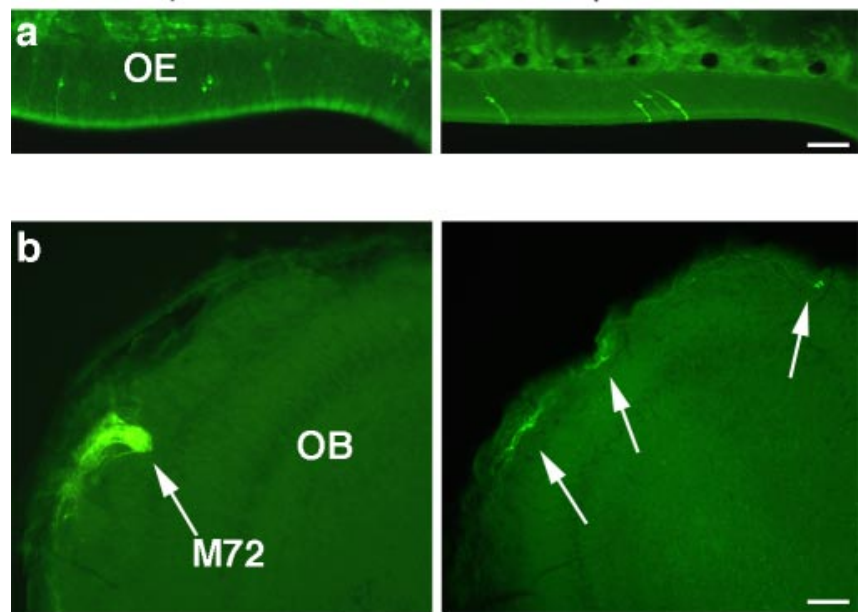

Figure 6. Axon guidance defects in the M72-odorant receptor neuron subset of $\beta 3 \mathrm{GnT}^{-1-}$ mice. $\boldsymbol{a}, \mathrm{GFP}^{+} \mathrm{M} 72$ neurons along the P10 dorsal septum of the M72-IRES-tauGFP reporter line crossed to $\beta 3 \mathrm{GnT}^{+/-}$and $\beta 3 \mathrm{GnT}^{-/-}$mice. Note that the $0 \mathrm{E}$ is significantly thinner at this age in mutant mice compared with the control $0 \mathrm{E}$. $\boldsymbol{b}, \mathrm{In}$ a coronal section through the wild-type $\mathrm{OB}, \mathrm{M} 72$ axons converge on a glomerulus on the dorsomedial surface of the extreme caudal OB. In $\beta 3 \mathrm{GnT1}$ mutant mice, at the same caudal OB position as controls, M72 axons primarily remain in the nerve layer and fail to converge on their typical glomerular position (arrows). Some M72 axons continue to grow past their normal termination site to the dorsalmost extent of the $O B$. Scale bars: $\boldsymbol{a}, 25 \mu \mathrm{m} ; \boldsymbol{b}, 50 \mu \mathrm{m}$.

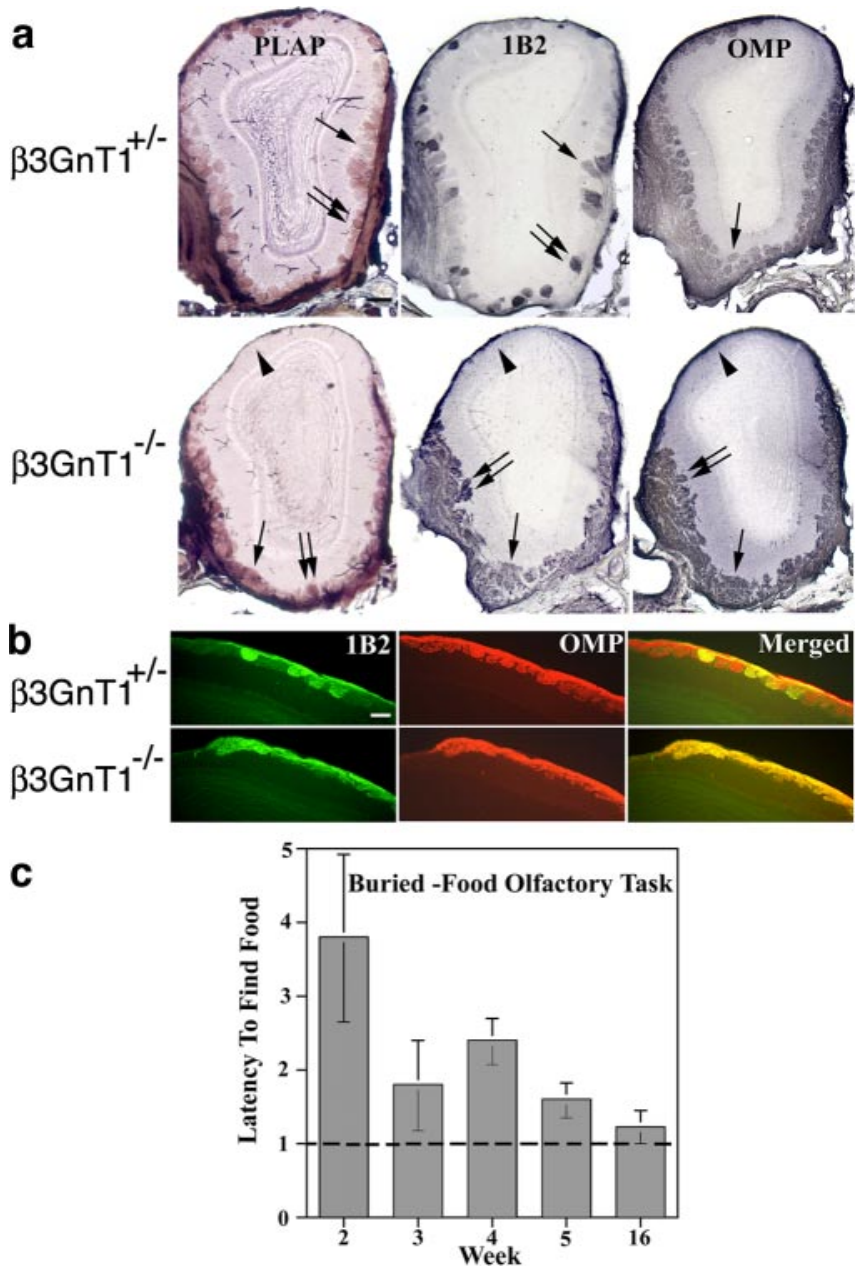

Figure 7. Expression of lactosamine in adult $\beta 3 \mathrm{GnT} 1$ null mice permits $\mathrm{OB}$ reinnervation and normal olfactory perception. $\boldsymbol{a}$, Histochemical staining for PLAP activity and ICC analysis of $1 \mathrm{~B} 2$ and OMP expression. Glomeruli (arrows) are grossly abnormal in mutant mice and mostly excluded from the dorsal OB (arrowheads). Scale bar, $200 \mu \mathrm{m}$. $\boldsymbol{b}$, Double-label immunofluorescence of $1 B 2$ (green), OMP (red), and both (overlay) in sagittal P25 OB sections. 1B2 is heavily expressed by all reinnervating fibers in null mice. Dorsal is up, and rostral is to the right. Scale bar, $100 \mu \mathrm{m}$. c, Olfactory performance of $\beta 3 \mathrm{GnT}^{-1-}$ mice relative to control littermates in food-finding task. Null mice remain significantly impaired at this task until adult ages, after lactosamine reexpression permits $\mathrm{OB}$ innervation. The dashed line denotes the baseline performance level of control littermates at each age.

mance in this test over a time course that paralleled lactosamine reexpression. By P35, null mice were only slightly delayed in food finding, and adult $\beta 3 \mathrm{GnT} 1^{-1-}$ mice were not statistically different from controls. Therefore, $\beta 3 \mathrm{GnT} 1$ ablation induced a transient smell perception deficit that abated after lactosamine reexpression, despite the formation of an extremely disorganized glomerular layer and the loss of some odorant receptor subsets. It is likely that the regeneration of other $\mathrm{OMP}^{+}$populations allows sufficient recovery of olfactory perception for the detection of complex food odorants that are central to survival. More extensive analysis with refined odorant compounds may, however, reveal residual deficits in olfactory perception in mutant mice, as the disorganization in the adult regenerated $\mathrm{OB}$ would suggest.

Loss of lactosamine and defects in other sensory areas of $\beta 3 \mathrm{GnT1}^{-1-}$ mice

$\beta 3 \mathrm{GnT} 1$ disruption also perturbed normal development in other sensory systems. Vomeronasal neurons at all developmental 


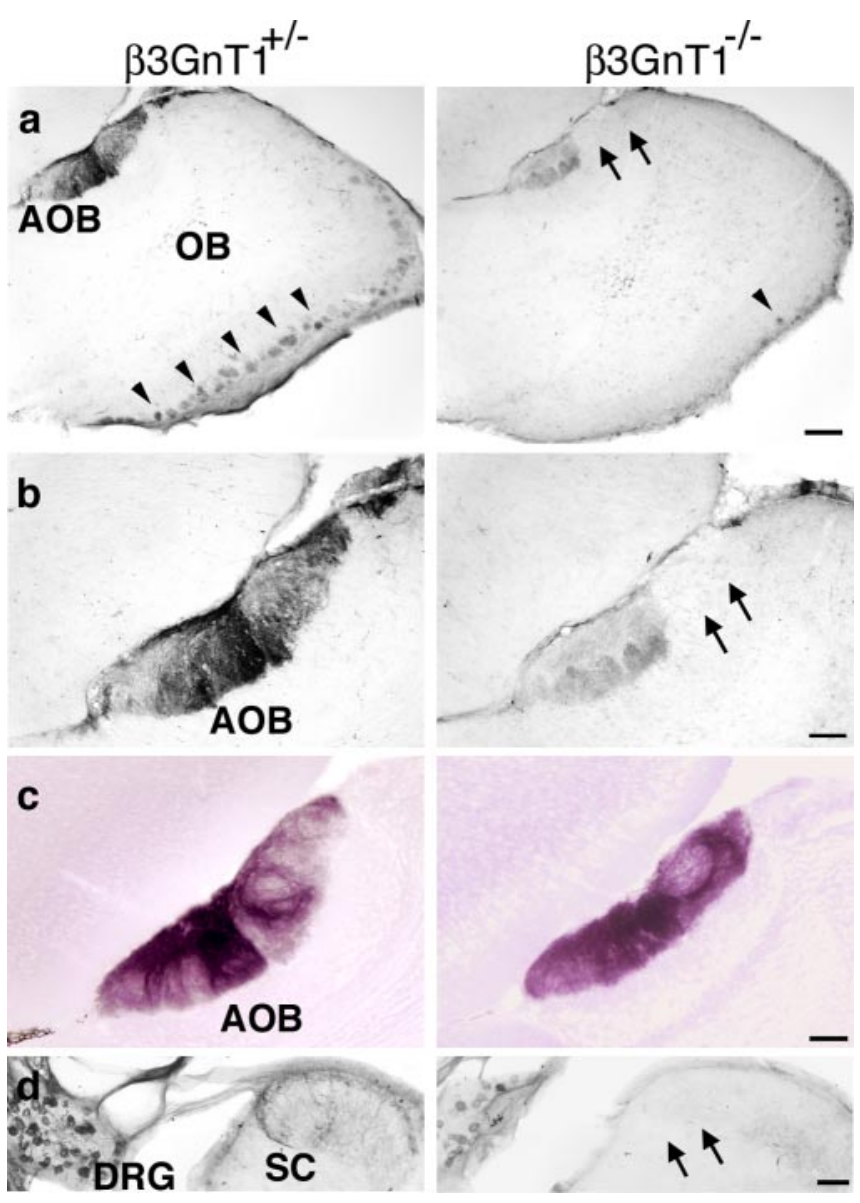

Figure 8. $\quad \beta 3 \mathrm{GnT} 1$ determines lactosamine expression in other sensory areas. $\boldsymbol{a}, 1 \mathrm{~B} 2$ labeling in sagittal $\mathrm{P} 10 \mathrm{OB}$ sections. Positions of $1 \mathrm{~B} 2^{+}$glomeruli in the ventral $\mathrm{OB}$ (arrowheads) and absent 1B2-labeling in $\beta 3 \mathrm{GnT}$ 1 null sections (arrows) are noted. $\boldsymbol{b}$, Higher-magnification view of the AOB from $\boldsymbol{a}$, showing detail of innervation by lactosamine-expressing axons. $\boldsymbol{c}$, PLAP histochemical labeling of axons in $A O B$ sections from the mouse shown in $\boldsymbol{b}$, showing complete correspondence between $\beta 3 \mathrm{GnT}$ 1-expressing fibers and $1 \mathrm{~B} 2$ reactivity. $\boldsymbol{d}, 1 \mathrm{~B} 2$ analysis of $\mathrm{P} 10$ DRG neurons and fibers innervating the dorsal horn of the spinal cord, which remains unlabeled in null mice. Unlike the $0 \mathrm{E}$, lactosamine is not reexpressed in either the $\mathrm{AOB}$ or $\mathrm{DRG}$ in adult null mice. Scale bars: $\boldsymbol{a}, 200 \mu \mathrm{m} ; \boldsymbol{b}-\boldsymbol{d}, 100 \mu \mathrm{m}$.

stages strongly expressed $\beta 3 \mathrm{GnT} 1$ (Fig. $1 c$ ). In control mice, axons from apical and basal vomeronasal compartments, which project to anterior and posterior accessory olfactory bulb (AOB) domains, respectively, were $1 \mathrm{~B} 2$-reactive (Fig. 8a,b). Lactosamine expression in $\beta 3 \mathrm{GnT} 1^{+/-} \mathrm{AOBs}$ colocalized completely with PLAP-expressing vomeronasal axons (Fig. $8 c$ ). In $\beta 3 \mathrm{GnT} 1^{-1-}$ mice, residual $1 \mathrm{~B} 2^{+}$fibers remained only in the posterior AOB. The area innervated by PLAP-expressing axons was $25 \%$ smaller in $\beta 3 \mathrm{GnT} 1^{-/-}$mice, implying a defect in $\mathrm{AOB}$ morphogenesis or, potentially, in $\mathrm{AOB}$ glomerular formation.

$1 \mathrm{~B} 2$ reactivity in DRGs was also primarily dependent on $\beta 3 \mathrm{GnT} 1$ expression. Lactoseries carbohydrates define a subpopulation of small and intermediate-diameter DRG neurons involved in transmission of cutaneous sensory information (Dodd and Jessell, 1985). $\beta 3 \mathrm{GnT} 1$ was strongly expressed in a subpopulation of DRG neurons at P10. $\beta 3 \mathrm{GnT} 1$ null mice had reduced 1B2 expression in DRG neurons and an absence of 1B2 ${ }^{+}$ axon collaterals projecting into the dorsal horn of the spinal cord (Fig. 8d).

\section{Discussion}

Lactosamine glycans have novel functions in sensory system development

We have identified a glycosyltransferase, $\beta 3 \mathrm{GnT} 1$, which is expressed predominantly by subsets of sensory neurons in the olfactory system, in cranial ganglia, and in DRGs. We also show that the expression of 1B2-reactive lactosamine glycans in the $\mathrm{OE}$ and these other sensory neurons is directly determined by $\beta 3 \mathrm{GnT} 1$ enzymatic activity. The loss of lactosamine in $\beta 3 \mathrm{GnT} 1$ mutant mice prevents olfactory projections from making connections with their intended synaptic partners in the OB. The results suggest that lactosamine may play a direct adhesive or signaling role in mediating axon-axon or axon-matrix interactions during development, and they provide strong genetic evidence for a cell-intrinsic function for glycans in axon pathfinding.

A plausible mechanism for such a function could involve galectins, a family of lactosamine-binding proteins, because several members of this family are expressed in the axon pathways (Mahanthappa et al., 1994; Storan and Key, 2004). In the olfactory system, galectin-1 is expressed by ensheathing glial cells in axon tracts between the OE and OB and is capable of modulating olfactory axon-axon interactions in vitro (Mahanthappa et al., 1994). Interestingly, galectin-1 was also postulated to participate in guidance of lactosamine-expressing DRG neurons to specific laminas of the spinal cord (Regan et al., 1986).

Alternatively, it is also possible that the loss of lactosamine affects the function of glycoproteins required for olfactory signal transduction. Genetic deletion of type-3 adenylyl cyclase, olfactory cyclic nucleotide-gated channel subunit 1 , and odorant receptors each produce OB innervation defects that are similar in some respects to those reported here for $\beta 3 \mathrm{GnT} 1^{-/-}$mice. Although it is clear from our analysis that some odorant receptors do not express lactosamine (see below), each of these signaling proteins is glycosylated (Gat et al., 1994; Bonigk et al., 1999; Wong et al., 2000). The particular glycans they express and their functional significance are now only beginning to be addressed. For example, complete removal of the single N-terminal glycosylation site of mOR-EG affects surface presentation of this odorant receptor in vitro (Katada et al., 2004). The loss of terminal lactosamine would be unlikely to perturb protein folding required for trafficking to the cell surface, however, because it would only be expected to affect late Golgi glycan processing. A more plausible lactosamine requirement could be in surface signaling complex assembly or dynamics. In this regard, decreases in lactosamine expression have been shown recently to influence the half-life of some growth factor receptors through the inhibition of endocytosis, an effect also ascribed to galectin interactions (Partridge et al., 2004). The possibility that lactosamine regulates surface expression of some components of the olfactory signaling apparatus awaits a detailed biochemical analysis of the glycosylation and stability of these glycoproteins in $\beta 3 \mathrm{GnT} 1$ null mice.

It is unclear whether glycosylation defects in one or multiple glycoproteins leads to the olfactory phenotype in $\beta 3 \mathrm{GnT}^{-/-}$ mice. Lactosamine is a common constituent of complex $N$-glycans in all cells but is typically capped by sialic acid or other saccharides that prevent 1B2 binding and contribute to masking of reactivity in tissues such as the CNS (Fig. 1a). Desialylation of tissue sections leads to broad $1 \mathrm{~B} 2$ reactivity in the $\mathrm{OB}$ and brain (Schwarting et al., 1992), suggesting that the selective expression of lactosamine by sensory neurons is unique. This is consistent with specialized functions for lactosamine in sensory develop- 
ment, which may reflect both tissue-specific $\beta 3 \mathrm{GnT} 1$ expression and the overt absence of additional lactosamine processing.

\section{B3GnT1 loss has heterogeneous effects on olfactory axon targeting}

$1 \mathrm{~B} 2$ reactivity in the postnatal $\mathrm{OE}$ is restricted to a population of differentiated apical sensory neurons and their axons, which suggests that lactosamine regulates connectivity with targets in the OB by affecting either axon sorting within the nerve layer or penetration into the glomerular layer. Severe deficits in OB innervation and glomerular formation were observed in three separate odorant receptor subsets, for which the timing and nature of the defects were heterogeneous. P2 axons from embryonic $\beta 3 \mathrm{GnT}^{-1-}$ mice primarily targeted the appropriate region of the OB but did not penetrate into the glomerular layer. Similarly, only a subpopulation of I7 axons reached the correct region of the nerve layer by P7, although a few fibers did innervate the presumptive I7 glomerulus. In both subsets, projections were not maintained after P10, suggesting that the absence of synaptic contact with mitral and tufted cells destabilized existing $\mathrm{OB}$ connections, compromising glomerular formation and olfactory neuron survival throughout postnatal life.

M72 neurons, however, exhibited a more specific axon guidance defect compared with P2 and I7 neurons. GFP-labeled M72 fibers projected diffusely to a large area of the dorsal posterior nerve layer and did not innervate glomeruli, indicating that lactosamine is specifically required for the targeting of some olfactory axon subsets. Heterogeneous effects on glomerular formation have been reported previously among different neuron subsets, which may reflect intrinsic differences in $\mathrm{OE}$ zone of receptor expression or the timing and region of $\mathrm{OB}$ innervation (Zheng et al., 2000; Potter et al., 2001; Yu et al., 2004). In $\beta 3$ GnT1 null mice, differences between subsets may also result from differential expression of lactosamine by neuron populations. The pattern of 1B2 reactive glomeruli is normally stereotyped in adult mice, with large variations in lactosamine expression among individual glomeruli (Fig. 7a) (Crandall et al., 2000). For example, $\mathrm{P} 2$ axons, which are lactosamine-positive, project to the anterior, ventral $\mathrm{OB}$, and form glomeruli early in development. In contrast, M72 axons, which are lactosamine negative, project to the posterior, dorsal $\mathrm{OB}$ and form glomeruli several days after P2 glomeruli (Potter et al., 2001).

Interestingly, M72 neurons and their projections appear more resilient in postnatal $\beta 3 \mathrm{GnT}^{-1-}$ mice than neurons of the $\mathrm{P} 2$ and I7 subsets, because GFP-labeled M72 fibers are at least detectable in the postnatal nerve layer. M72 axons grow to and beyond their intended targets in the $\mathrm{OB}$, suggesting that lactosamine influences guidance of axon populations that do not directly express lactosamine. This is very similar to axon guidance mistakes in Sema3 $\mathrm{A}^{-1-}$ mice, in which axons that do not express neuropilin-1, the Sema3A receptor, are also often misguided because of perturbations caused by severe misrouting of neuropilin $-1^{+}$axons (Schwarting et al., 2004). It may be that M72 axons fail to converge on their correct target because of secondary changes in the nerve and glomerular layers after the loss of other neuron populations and their projections early in development.

\section{Factors that influence survival and regeneration of $\beta 3 \mathrm{GnT}^{-1-}$ sensory neurons}

In P10 mutant mice, several residual, 1B2-immunoreactive glomeruli are visible in the OB (Fig. $2 b$ ). This implies that an alternative mechanism for producing lactosamine exists in a small subset of olfactory neurons, potentially the same pathway that is upregulated during the regeneration phase. This observation also suggests that lactosamine confers the ability of olfactory axons to grow into the $\mathrm{OB}$, to form glomeruli, and to survive. It also raises the question of how many odorant receptors remain and what factors are responsible for reconstituting the adult olfactory system in $\beta 3 \mathrm{GnT} 1$ adult mutants, in which all axons express lactosamine. Perhaps olfactory neurons in adult $\beta 3 \mathrm{GnT} 1$ mutants express a reduced repertoire of odorant receptor subtypes, which survive and form connections, in part, because they are able to activate this alternative lactosamine synthesis mechanism.

The defects in embryonic development described here show similarities to other rodent olfactory degeneration models that show that survival of olfactory sensory neurons requires trophic signals derived from the OB (Schwob et al., 1992; Holcomb et al., 1995; Weiler and Farbman, 1999). In $\beta 3 \mathrm{GnT} 1$ null mice, $\sim 30 \%$ of P2 and I7 neurons are lost embryonically, before mature glomerular formation and exposure to the external odor environment. This prenatal deletion is distinct from null phenotypes reported for global ablation of olfactory signal transduction genes, which widely fail to alter neuronal subsets or disrupt initial glomerular targeting (Brunet et al., 1996; Belluscio et al., 1998; Zhao and Reed, 2001), and suggests that lactosamine interactions are required for axons to connect with and obtain trophic support from targets in the embryonic OB. Postnatally, the absence of synaptic contact in $\beta 3 \mathrm{GnT} 1^{-/-}$sensory neurons precludes odor-evoked activity for the majority of axons that do not enter the glomerular layer, which likely further compromises neuronal survival.

It is less clear why the three specific subsets of neurons we examined in reporter mice crossed to $\beta 3 \mathrm{GnT} 1$ nulls continue to be lost during the regeneration phase, whereas other $\mathrm{OMP}^{+}$neuron populations survive to repopulate the OE. Genetic studies have shown that neuron subsets that are deficient in synaptic activity, either through loss of olfactory signal transduction (Zhao and Reed, 2001) or through inhibition of synaptic vesicle release (Yu et al., 2004), are gradually deleted from the odorant receptor repertoire through failed competition with functionally active neurons. These observations are relevant to the recovery of individual neuronal populations observed in $\beta 3 \mathrm{GnT} 1$ null mice, in which, despite the widespread reexpression of lactosamine, the population of P2 and I7 odorant receptor neurons decreased postnatally until $<15 \%$ of the normal number remained in adults. One possibility is that variations in sensory experience attributable to differences in environmental odor ligand exposure could lead to variations in recovery, a hypothesis previously suggested from chemical lesioning models of olfactory regeneration (Iwema et al., 2004). It is also possible that some subsets of sensory neurons are unable to de novo express lactosamine during the regeneration phase. Finally, we cannot exclude the possibility that some sensory neurons are lost from detection through odorant receptor switching instead of cell death (Serizawa et al., 2003).

\section{$\beta 3 \mathrm{GnT} 1$ and other sensory systems}

The retinotectal system has often been used as a model to better understand mechanisms used to construct connections in the developing olfactory system (Key and St John, 2002). Studies presented here suggest that it may be helpful to consider the patterning of DRG projections to the dorsal horn of the spinal cord as an alternative model. Interestingly, there are parallels between axon targeting by $\mathrm{OE}$ neurons to the $\mathrm{OB}$ and nociceptive DRG neurons to the spinal cord. Both create spatial order by converging input from dispersed sensory neurons to specific tar- 
get zones (OB glomeruli and dorsal horn laminas). It will be informative to determine whether the topography of DRG projections in $\beta 3 \mathrm{GnT}^{-1-}$ mice is disrupted similarly to the abnormal olfactory connectivity described here. Furthermore, because $\beta 3 \mathrm{GnT} 1$ is expressed by subsets of other cranial neurons, including trigeminal and glossopharyngeal neurons, it will be of additional significance to contemplate a conserved function for lactosamine in building circuitry in other sensory systems.

\section{References}

Belluscio L, Gold GH, Axel R (1998) Mice deficient in G(olf) are anosmic. Neuron 20:69-81.

Bonigk W, Bradley J, Muller F, Sesti F, Boekhoff I, Ronnett GV, Kaupp UB, Frings S (1999) The native rat olfactory cyclic nucleotide-gated channel is composed of three distinct subunits. J Neurosci 19:5332-5347.

Brunet LJ, Gold GH, Ngai J (1996) General anosmia caused by targeted disruption of the mouse olfactory cyclic nucleotide-gated cation channel. Neuron 17:681-693.

Crandall JE, Dibble C, Butler D, Pays L, Ahmad N, Kostek C, Püschel AW, Schwarting GA (2000) Patterning of olfactory sensory connections is mediated by extracellular matrix proteins in the nerve layer of the olfactory bulb. J Neurobiol 45:195-206.

Cutforth T, Moring L, Mendelsohn M, Nemes A, Shah NM, Kim MM, Frisan J, Axel R (2003) Axonal ephrin-As and odorant receptors: coordinate determination of the olfactory sensory map. Cell 114:311-322.

Dobritsa AA, van der Goes van Naters W, Warr CG, Steinbrecht RA, Carlson JR (2003) Integrating the molecular and cellular basis of odor coding in the Drosophila antenna. Neuron 37:827-841.

Dodd J, Jessell TM (1985) Lactoseries carbohydrates specify subsets of dorsal root ganglion neurons projecting to the superficial dorsal horn of rat spinal cord. J Neurosci 5:3278-3294.

Ebrahimi FA, Chess A (2000) Olfactory neurons are interdependent in maintaining axonal projections. Curr Biol 10:219-222.

Gat U, Nekrasova E, Lancet D, Natochin M (1994) Olfactory receptor proteins. Expression, characterization and partial purification. Eur J Biochem 225:1157-1168.

Gibson NJ, Hildebrand JG, Tolbert LP (2004) Glycosylation patterns are sexually dimorphic throughout development of the olfactory system in Manducta sexta. J Comp Neurol 476:1-18.

Henion TR, D. Zhou D, Wolfer DP, Jungalwala FB, Hennet T (2001) Cloning of a mouse $\beta 1,3-N$-acetylglucosaminetransferase $\operatorname{GlcNAc}(\beta 1,3) \operatorname{Gal}(\beta 1,4)$ Glcceramide synthase gene encoding the key regulator of lacto-series glycolipid biosynthesis. J Biol Chem 276:30261-30269.

Holcomb JD, Mumm JS, Calof AL (1995) Apoptosis in the neuronal lineage of the mouse olfactory epithelium: regulation in vivo and in vitro. Dev Biol 172:307-323.

Hummel T, Zipursky SL (2004) Afferent induction of olfactory glomeruli requires $N$-cadherin. Neuron 42:77-88.

Iwai T, Inaba N, Naundorf A, Zhang Y, Gotoh M, Iwasaki H, Kudo T, Togayachi A, Ishizuka Y, Nakanishi H, Narimatsu H (2002) Molecular cloning and characterization of a novel UDP-GlcNAc:GalNAc-peptide beta1,3- $N$-acetylglucosaminyltransferase (beta $3 \mathrm{Gn}-\mathrm{T} 6$ ), an enzyme synthesizing the core 3 structure of $O$-glycans. J Biol Chem 277:12802-12809.

Iwema CL, Fang H, Kurtz DB, Youngentob SL, Schwob JE (2004) Odorant receptor expression patterns are restored in lesion-recovered rat olfactory epithelium. J Neurosci 24:356-369.

Katada S, Tanaka M, Touhara K (2004) Structural determinants for membrane trafficking and $\mathrm{G}$ protein selectivity of a mouse olfactory receptor. J Neurochem 90:1453-1463.

Key B, St John J (2002) Axon navigation in the mammalian primary olfactory pathway: where to next? Chem Senses 27:245-260.

Leighton PA, Mitchell KJ, Goodrich LV, Lu X, Pinson K, Scherz P, Skarnes WC, Tessier-Lavigne M (2001) Defining brain wiring patterns and mechanisms through gene trapping in mice. Nature 410:174-179.

Lipscomb BW, Treolar HB, Greer CA (2002) Cell surface carbohydrates reveal heterogeneity in olfactory receptor axons in the mouse. Cell Tissue Res 308:7-17.

Lipscomb BW, Treloar HB, Klenoff J, Greer CA (2003) Cell surface carbohydrates and glomerular targeting of olfactory sensory neuron axons in the mouse. J Comp Neurol 467:22-31.

Mahanthappa NK, Cooper DNW, Barondes SH, Schwarting GA (1994) Rat olfactory neurons can utilize the endogenous lectin, L-14, in a novel adhesion mechanisms. Development 120:1373-1384.

Malissard M, Dinter A, Berger EG, Hennet T (2002) Functional assignment of motifs conserved in $\beta 1,3$-glycosyltransferases. Eur J Biochem 269:233-239.

Mitchell KJ, Pinson KI, Kelly OG, Brennan J, Zupicich J, Scherz P, Leighton PA, Goodrich LV, Lu X, Avery BJ, Tate P, Dill K, Pangilinan E, Wakenight P, Tessier-Lavigne M, Skarnes WC (2001) Functional analysis of secreted and transmembrane proteins critical to mouse development. Nat Genet 28:241-249.

Mombaerts P, Wang F, Dulac C, Chao SK, Nemes A, Mendelsohn M, Edmondson J, Axel R (1996) Visualizing an olfactory sensory map. Cell 87:675-686.

Partridge EA, Le Roy C, Di Guglielmo GM, Pawling J, Cheung P, Granovsky M, Nabi IR, Wrana JL, Dennis JW (2004) Regulation of cytokine receptors by Golgi $N$-glycan processing and endocytosis. Science 306:120-124.

Pasterkamp RJ, De Winter F, Holtmaat AJ, Verhaagen J (1998) Evidence for a role of the chemorepellent semaphorin III and its receptor neuropilin-1 in the regeneration of primary olfactory axons. J Neurosci 18:9962-9976.

Potter SM, Zheng C, Koos DS, Feinstein P, Fraser SE, Mombaerts P (2001) Structure and emergence of specific olfactory glomeruli in the mouse. J Neurosci 21:9713-9723.

Regan LJ, Dodd J, Barondes SH, Jessell TM (1986) Selective expression of endogenous lactose-binding lectins and lactoseries glycoconjugates in subsets of rat sensory neurons. Proc Natl Acad Sci USA 83:2248-2252.

Ressler KJ, Sullivan SL, Buck LB (1993) A zonal organization of odorant receptor gene expression in the olfactory epithelium. Cell 73:597-609.

Royal SJ, Key B (1999) Development of P2 olfactory glomeruli in P2internal ribosome entry site-tau-LacZ transgenic mice. J Neurosci 19:9856-9864.

Sasaki K, Kurata-Miura K, Ujita M, Angata K, Nakagawa S, Sekine S, Nishi T, Fukuda M (1997) Expression cloning of cDNA encoding a human $\beta-1,3-N$-acetylglucosaminyltransferase that is essential for poly- $N$ acetyllactosamine synthesis. Proc Natl Acad Sci USA 94:14294-14299.

Schwarting GA, Crandall JE (1991) Subsets of olfactory and vomeronasal sensory epithelial cells and axons revealed by monoclonal antibodies to carbohydrate antigens. Brain Res 547:239-248.

Schwarting GA, Deutsch G, Gattey DM, Crandall JE (1992) Glycoconjugates are stage and position-specific cell surface molecules in the developing olfactory system. II. Unique carbohydrate antigens are topographic markers for selective projection patterns of olfactory axons. J Neurobiol 23:130-142.

Schwarting GA, Kostek C, Ahmad N, Dibble C, Pays L, Püschel AW (2000) Semaphorin $3 \mathrm{~A}$ is required for normal guidance of olfactory axons in mice. J Neurosci 20:7691-7697.

Schwarting GA, Raitcheva D, Crandall JE, Burkhardt C, Püschel AW (2004) Semaphorin 3A-mediated axon guidance regulates convergence and targeting of P2 odorant receptor axons. Eur J Neurosci 19:1800-1810.

Schwartz-Levy M, Chikaraishi DM, Kauer JS (1991) Characterization of potential precursor populations in the mouse olfactory epithelium using immunocytochemistry and autoradiography. J Neurosci 11:3556-3564.

Schwob JE, Szumowski KE, Stasky AA (1992) Olfactory sensory neurons are trophically dependent on the olfactory bulb for their prolonged survival. J Neurosci 10:3896-3919.

Schwob JE, Youngentob SL, Mezza RC (1995) Reconstitution of the rat olfactory epithelium after methyl bromide-induced lesion. J Comp Neurol 359:15-37.

Serizawa S, Miyamichi K, Nakatani H, Suzuki M, Saito M, Yoshihara Y, Sakano H (2003) Negative feedback regulation ensures the one receptor-one olfactory neuron rule in mouse. Science 302:2088-2094.

Storan MJ, Key B (2004) Target tissue influences the peripheral trajectory of mouse primary sensory olfactory axons. J Neurobiol 61:175-188.

Vassar R, Chao SK, Sitcheran R, Nunez JM, Vosshall LB, Axel R (1994) Topographic organization of sensory projections to the olfactory bulb. Cell 79:981-991.

Voyron S, Giacobini P, Tarozzo G, Cappello P, Perroteau I, Fasolo A (1999) Apoptosis in the development of the mouse olfactory epithelium. Brain Res Dev Brain Res 115:49-55.

Wang F, Nemes A, Mendelsohn M, Axel R (1998) Odorant receptors govern the formation of a precise topographic map. Cell 93:47-60.

Wang SS, Lewcock JW, Feinstein P, Mombaerts P, Reed RR (2004) Genetic 
disruptions of $\mathrm{O} / \mathrm{E} 2$ and $\mathrm{O} / \mathrm{E} 3$ genes reveal involvement in olfactory receptor neuron projection. Development 131:1377-1388.

Weiler E, Farbman AI (1999) Mitral cell loss following lateral olfactory tract transection increases proliferation density in rat olfactory epithelium. Eur J Neurosci 11:3265-3275.

Wong ST, Trinh K, Hacker B, Chan GC, Lowe G, Gaggar A, Xia Z, Gold GH, Storm DR (2000) Disruption of the type III adenylyl cyclase gene leads to peripheral and behavioral anosmia in transgenic mice. Neuron 27:487-497.

Wrenn CG, Harris AP, Saavedra MC, Crawley JN (2003) Social transmission of food preference in mice: methodology and application to galininoverexpressing transgenic mice. Behav Neurosci 117:21-31.

Yeh JC, Hiraoka N, Petryniak B, Nakayama J, Ellies LG, Rabuka D, Hindsgaul O, Marth JD, Lowe JB, Fukuda M (2001) Novel sulfated lymphocyte homing receptors and their control by a Corel extension $\beta 1,3-N$ acetylglucosaminyltransferase. Cell 105:957-969.
Young WW, Portoukalien J, Hakomori SI (1981) Two monoclonal anticarbohydrate antibodies directed to glycosphingolipids with a lacto- $\mathrm{N}$ glycosyl type II chain. J Biol Chem 256:10967-10972.

Yu CR, Power J O’Donnell S, Brown HE, Osborne J, Axel R, Gogos JA (2004) Spontaneous neural activity is required for the establishment and maintenance of the olfactory sensory map. Neuron 42:553-566.

Zhao H, Reed RR (2001) X inactivation of the ONCNC1 channel gene reveals a role for activity-dependent competition in the olfactory system. Cell 104:651-660.

Zheng C, Feinstein P, Bozza T, Rodriguez I, Mombaerts P (2000) Peripheral olfactory projections are differentially affected in mice deficient in a cyclic nucleotide-gated channel subunit. Neuron 2000 26:81-91.

Zhou D, Dinter A, Gutierres Gallego R, Kamerling JP, Vliegenthart JF, Berger EG, Hennet T (1999) A $\beta-1,3-N$-acetylglucosaminyltransferase with poly- $N$-acetyllactosamine synthase activity is structurally related to $\beta$-1,3-galactosyltransferase. Proc Natl Acad Sci USA 96:406-411. 